\title{
Agroforestry - an opportunity overlooked?
}

\author{
M.F. Hawke' and J.P. Maclaren ${ }^{2}$ \\ 'MAFTech, Box 951, Rotorua ${ }^{2}$ FRI, Rotorua
}

ABSTRACT Agroforestry is defined, and shown to be a very profitable option for hill country farmers. It is suggested that agroforestry should be part of a normal farm portfolio of investments. A 30 to 50 -hectare woodlot can be worth a million dollars to the grower, and thus be worth more than the rest of the farm combined. Research on agroforestry by combined forestry and agricultural scientists has been extensive, and many potential useful discoveries have been made. Worthwhile pasture production can be achieved for half of the tree rotation and good livestock performance is possible under low tree populations. Nevertheless, this technology has not been taken up by farmers, possibly because profit from trees is not considered to be an important use of trees, as two surveys indicate.

K eywords agroforestry, profitability, opportunity, potential, hill country

\section{INTRODUCTION}

The term 'agroforestry' has been widely used in many countries for several decades. Unfortunately, it still means different things to different people, so it is necessary to define it.

To researchers in the Ministries of Agriculture and Forestry, agroforestry is defined as:

"an "umbrella" term covering a wide range of land uses where woody perennials, including trees, are managed on a vertically integrated system with agriculture' (Butcher 1986).

Forest grazing is the most important component of agroforestry that involves the greatest area of land. About 60000 ha of large plantation forests are currently being grazed, and there is potential for 168 000 ha (Hammond 1986). Essential elements of forest grazing (as opposed to use of forests as run-off blocks) are the introduction of a legume, such as 'Grasslands Maku' lotus, and the management of the operation for the sake of the trees, the understorey and the livestock.

Timberbelts are the next most important component of agroforestry in New Zealand. These are shelterbelts that are managed to enhance the value of the timber at harvest. The usefulness of timberbelts for shelter may or may not be important to the manager. Timberbelts can be seen as "forestry in single rows".

The third type of agroforestry is trees-on-pasture. It is surprising that many New Zealanders think only of this form of land-use when they hear the word 'agroforestry'. The purpose of this paper is to investigate the reasons why 'trees-on-pasture' has not been widely adopted, despite widespread awareness of the concept, and despite thorough research from both the agricultural and the forestry perspectives.

-Trees-on-pasture describes the situation where trees are planted onto existing pasture of reasonable quality. The pasture is grazed as soon as the manager is confident that tree damage will not eventuate, and the pasture continues to be grazed for as long as it is worthwhile to do so. This combined form of land-use is an attempt to attain a profitability greater than that yielded by pure forestry or pure grazing.

The 'trees' referred to in this paper are Pinus radiata, because the vast bulk of agroforestry research has been done with this species, and because the technology is proven. Forceful advocates of 'alternative' species of tree are easily found, but we strongly believe that no other timber species has been demonstrated to equal or even approach the profitability and reliability of radiata pine for general agroforestry use.

\section{THE PROFITABILITY OF AGROFORESTRY}

Agroforestry has been shown to be a profitable form of land use. For example, Knowles \& West (1986), in a demonstration exercise, concluded that (for their chosen set of assumptions) agroforestry was more profitable than grazing in situations where farming gross margin was less than $\$ \mathbf{4 0 0} / \mathbf{h a}$. Assumptions used included interest rates of $4 \%$ to $10 \%$, timber prices predicted by a computer model, and livestock gross margins of \$25/LSU. Nevertheless, Knowles \& West stated that agroforestry (or any form of forestry) is unlikely to be profitable on remote, steep, weedinfested land of poor quality.

The volumes obtained in Table 1 are from Whiteside (1989) and represent a typical North island site of medium fertility, with a site index of $30 \mathrm{~m}$. (Note that agroforestty sites are usually classified as 'high fertility' and can be expected to yield much higher volumes (West 1986)). The first of each pair of price columns in Table 1 is from G. Horgan (unpublished data, 1989) and is a compilation of market prices obtained from a variety of sources. The second column is obtained from computer simulation studies combined with benchmark figures obtained from industry (Whiteside, unpublished data, 1989). In both cases, the current national average cost of $\$ 26 / \mathrm{m}^{3}$ for logging, loading and transport is assumed. If agroforestry sites are less steep or less remote, then this figure would be substantially lower, and stumpage prices should be higher.

In a recent address to a Taranaki agroforestry seminar, Knowles (pers. comm.) stated that a woodlot can be worth up to $\$ 40,000$ per hectare to the grower 
(after costs). To obtain this high figure, he stated that the combination of factors (site, location and silviculture) must be near optimum. Olsen (1985) gives many examples to demonstrate that small woodlots can be almost as profitable per hectare as large-scale operations. The profitability of large-scale plantation forestry is generally accepted, and is reflected in the high (and rising) values of shares in forestry. Values are projected to increase further, and BERL (1988) has even predicted a doubling by the year 2010 .

Sutton (1981) argues that forestry faces a bright future, particularly if we produce a scarce product. The increasing unavailability of indigenous forests around the world presents New Zealand with a market opportunity. Such forests produced large logs containing a high percentage of clearwood (i.e. knotfree wood). We have the means of growing similar trees by pruning and thinning. Timely pruning ensures

Table 1 The revenue obtainable from a stand of radiata pine, carrying $250 \mathrm{stems} / \mathrm{ha}$, pruned to $6.0 \mathrm{~m}$, and clearfelled at age 28. Figures are. expressed on a per hectare basis.

\begin{tabular}{lcccrr}
\hline & \multicolumn{3}{c}{$\begin{array}{c}\text { Merchantable Stumpage } \\
\text { Log grade } \\
\text { volume }\left(\mathbf{m}^{\mathbf{3}}\right)\end{array}$} & \multicolumn{3}{c}{$\begin{array}{c}\text { Revenue } \\
\mathbf{( \$ \mathbf { m }} \mathbf{\mathbf { 3 }})\end{array}$} \\
\hline Pruned logs & 157 & 84 & 86 & 13188 & 13502 \\
S1 and S2 & $\mathbf{1 5}$ & 34 & 47 & 510 & 705 \\
L1 and L2 & 263 & 9 & 35 & 2367 & 9205 \\
Other (pulp) & 149 & 4 & 14 & 596 & 2086 \\
TOTAL & 584 & & & 16661 & 25498 \\
\hline
\end{tabular}

that the butt $\log$ is relatively knot-free, and early thinning down to low final crop stockings ensures a large diameter tree at an early age. Such regimes are referred to as 'direct sawlog' or 'clearwood' regimes. It does not usually pay a small forest owner to attempt to sell thinnings for a profit. Returns from such wood are low, and the growth of the final crop is slowed.

The grower, of course, receives the revenue when the trees are mature, say at 28 years old. The central problem is the delay between the outlay of capital at planting and the receipt of the revenue at harvest.

Nevertheless, immature forests are not totally devoid of value. They constitute assets, which can be used as collateral. Alternatively, they can be sold in their immature state to an investor who is prepared to "grow them on' to harvest. Immature trees can be sold independently of the land (Groome 1986).

With direct sawlog regimes, understorey grazing can be substantial, and help to offset the cost of the venture. The extent of grazing will depend on the tree age and stocking (shading reduces pasture), and the silviculture operations used. Thinning and pruning create debris which covers pasture. Although the effect of the trees on the pasture is largely negative, the opposite is not true. Nutrient recycling can result in an increase in growth (in terms of 'basal area') of up to $40 \%$ (West 1986), until the time of canopy closure. Fire risk is reduced, and also the cost of silvicultural operations, because of a reduction in weeds and hence time spent walking between trees.
Many years of intensive research by agricultural and forestry scientists have resulted in computer models that can predict the physical and final consequences of most combinations of trees, pasture and livestock (Cox et al. 1986). Such models confirm field observations: in most instances forestry is a profitable alternative to sheep for hill country farmers, and agroforestry even more so. But to realise the profit, it is important to use modern forestry regimes and good management skills (forestry and pastoral). Details of these are described by various authors in Maclaren (1988).

Table 2 Effect of stocking and age of radiata pine on pasture dry matter production (expressed as a \% of production on open pasture, i.e. no trees). (From the joint MAF/MOF trial at Tikitere).

\begin{tabular}{|c|c|c|c|c|}
\hline \multirow[t]{2}{*}{$\begin{array}{l}\text { Tree age } \\
\text { (years) }\end{array}$} & \multicolumn{4}{|c|}{ Final tree stocking (stems/ha) } \\
\hline & 50 & 100 & 200 & 400 \\
\hline $\begin{array}{l}3 \\
8 \\
13\end{array}$ & $\begin{array}{r}116 \\
92 \\
85\end{array}$ & $\begin{array}{c}92 \\
89 \\
50\end{array}$ & $\begin{array}{l}92 \\
72 \\
18\end{array}$ & $\begin{array}{l}80 \\
53 \\
\mathbf{n} / \mathbf{a}\end{array}$ \\
\hline
\end{tabular}

$\mathrm{n} / \mathrm{a}=$ not measured

\section{AGRICULTURAL RESEARCH RESULTS}

The quantity of pasture declines with tree age and tree stocking (Table 2). The decline is rapid when canopy closure occurs, e.g. years $12-13$ at $200 \mathrm{sph}$.

Pasture composition changes with time under trees (Figure 1). The ryegrass and white clover content gradually declines. Secondary grasses (Yorkshire fog, poa species and sweet vernal) increased from $32 \%$ at age 9 to $45 \%$ at age 12 and decaying pine needles accumulated from $10 \%$ to $47 \%$, at a tree stocking of 200 sph.

On an integrated agroforestry system, the ability to carry $46 \%$ of the livestock numbers under $100 \mathrm{sph}$ (relative to no trees) half way through the tree rotation enhances the profitability of the enterprise (Table 3).

Of equal importance to livestock farmers is animal performance. A series of trials run over several years has demonstrated the following effects.

1) Ewe liveweight, lamb weaning weights and fleece weights are depressed with increasing tree stocking and age when managed on an area that is totally under agroforestry (Percival et al. 1986) (Table 4).

2) In feed allowance studies, lamb liveweight gain indicates reduced performance with increasing tree stocking (from Hawke, 1989) (Figure 2).

Previous papers to Grassland Conferences have detailed livestock management requirements and general recipes for successful agroforestry (Hawke \& Percival 1984; Gillingham et al. 1976). Although the work has involved mainly sheep as the chosen type of livestock, cattle and deer have also been farmed successfully in the 'trees-on-pasture' system. Feral and farmed goats, however, have given a few problems, mainly owing to their propensity to strip bark from immature and semi-mature trees. 


\section{OTHER FACTORS}

For tax purposes, farmers can deduct up to $\$ 7500$ per year of the costs associated with establishing and maintaining woodlots. This is sufficient to enable 15-20 ha to be established and maintained every year. Various farmers have shown that radiata pine agroforestry can be a low-cost form of investment, as most of the work can be done by the family (e.g. Brann \& Brann 1988). At harvest time, revenue can be spread back over the previous 5 years to provide some flexibility in controlling tax take.

But there are many reasons for planting trees other than profit from the timber. Shelter for livestock,

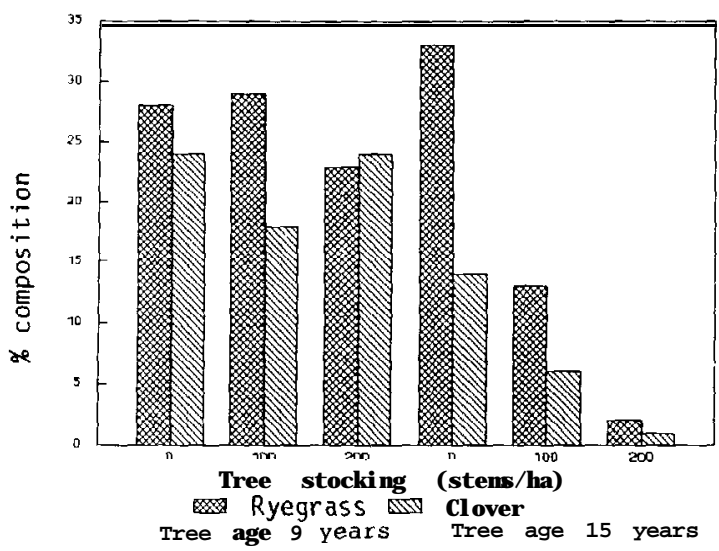

Figure 1 Effect of tree age and stocking on percentage pasture composition.

homestead and farm buildings can be important in some climates. Water quality is enhanced in a forested catchment (O'Laughlin \& Will 198 1), and there could be aesthetic or wildlife reasons for the use of trees. Trees can be very useful in countering some forms of soil erosion (O'Loughlin 1981) and forestry was successful in this respect on the East Coast during Cyclone Bola, provided that tree age was greater than 8 years (Trotter 1988).

\section{FAILURE TO IMPLEMENT AGROFORESTRY}

Given that trees-on-pasture is a proven, profitable alternative to conventional hill country farming, why has it not been widely adopted? Hammond (1986) reported that there were only 149 small growers of

Table 3 Effect of stocking and age of radiata pine on livestock numbers carried, relative to open pasture $(=100)$. (From the joint MAF/MOF trial at Tikitere).

\begin{tabular}{|c|c|c|c|c|}
\hline \multirow[t]{2}{*}{$\begin{array}{l}\text { Tree age } \\
\text { (years) }\end{array}$} & \multicolumn{4}{|c|}{ Tree density (stems/ha) } \\
\hline & 50 & 100 & 200 & 400 \\
\hline 5 & 96 & 89 & 67 & 30 \\
\hline 9 & & 78 & 49 & 21 \\
\hline 12 & 76 & 46 & 21 & $3(\mathrm{est})$ \\
\hline
\end{tabular}

agroforestry, and that these accounted for a mere 2035 hectares.

Some of the reasons for this are answered in surveys undertaken by Smaller \& Meister (1983) and Morey (1986), whereby profit was declared to be an unimportant reason for planting trees. In fact, in the extensive and detailed Morey survey, profit from sale of timber was described as the least important use of

Table 4 Effects of tree stocking on ewe liveweight, wool weight and lamb growth rates at the Tikitere Forest Farming Research Area (taken from Percival et al. 1984).

\begin{tabular}{|c|c|c|c|c|c|c|}
\hline & $\begin{array}{c}\text { Tree } \\
\text { age } \\
\text { (years) }\end{array}$ & Nil & $\begin{array}{c}\text { Tree } \\
\text { Stockin } \\
50\end{array}$ & $\begin{array}{c}\text { ha) } \\
100\end{array}$ & 200 & SED \\
\hline \multirow{2}{*}{$\begin{array}{l}\text { Liveweight changes' } \\
\text { (g/ewe/day) }\end{array}$} & 8 & 18 & 11 & 11 & -7 & 4 \\
\hline & 9 & 24 & 4 & 12 & 19 & 2 \\
\hline \multirow{2}{*}{$\begin{array}{l}\text { Wool weights }{ }^{2} \\
(\mathrm{~kg} \quad \text { fleece/ewe) }\end{array}$} & 8 & 3.2 & 2.9 & 3.1 & 2.6 & 0.1 \\
\hline & 9 & 3.3 & 2.8 & 2.9 & 2.8 & 0.1 \\
\hline \multirow{2}{*}{$\begin{array}{l}\text { Lamb growth rates } \\
\text { (g/lamb/day) }\end{array}$} & 8 & 189 & 189 & 184 & 160 & 5 \\
\hline & 9 & 182 & 175 & 170 & 167 & 8 \\
\hline
\end{tabular}

over 12 months from a common starting weight.

'taken over 5-7 months.

forest trees on farms. Have farmers or their advisors not received the message about the extent of profit that trees can provide?

The news media have stressed the financial hardship endured by hill country farmers in recent years. It is, therefore, hard to understand the low importance of profit from trees in their list of priorities. Morey (loc.cit.) lists the main uses of trees, in order, with opinions from a sample of 1600 farmers:

Important: shelter stock; shelter house; landscape - aesthetics; best land use.

Not particularly important: erosion control; own supply; farm value; profit from sale.

In other words, hard-up farmers (and presumably their advisors) place the aesthetics of forestry well ahead of profit from timber!

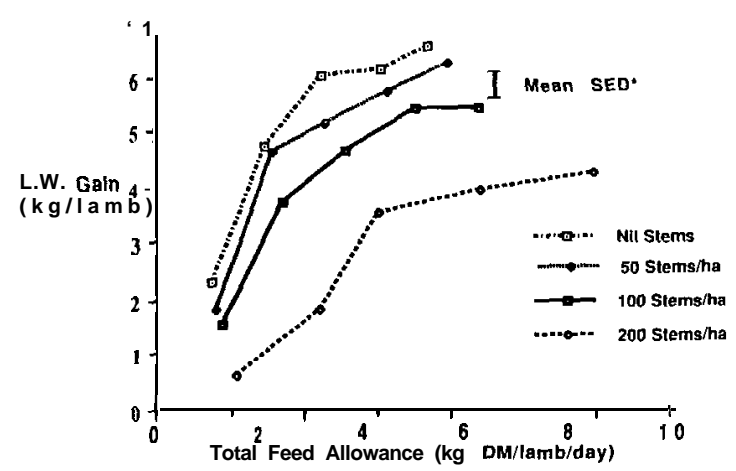
- SED varles from $\mathbf{0 . 4 2 \cdot 0 . 6 4}$

Figure 2 Effect of total feed available on liveweight gain of lambs under a range of tree populations. 
When Morey asked respondents to give their reasons for not planting trees, there were no important or outstanding reasons. Lack of information was (in the farmers' opinion, anyway) not an important reason.

In a third question, Morey asked for the main sources of forestry information.

Important: magazines.

Not particularly important: NZFS extension officers; neighbours and friends; Farm Forestry Association; catchment boards; MAF farm advisors; Forest Owners Association; private consultants.

What can be deduced from the above? Most scientists involved in forestry and agroforestry research have not contributed greatly to popular magazines. In our opinion, MAF farm advisors have, for the most part, been uninformed or negative about agroforestry

If, indeed, education of farmers is the problem, then the solution is to start at the source: agricultural training and forestry training have traditionally been separate disciplines in New Zealand, and there are few advisors who can boast qualifications in both. Secondly, agricultural organisations need to accept that agroforestry is not an 'alternative land-use', but an opportunity for most farmers. Trees are just another cash crop for the farmer. Agricultural advisors should be advocating woodlots as part of a normal farm portfolio of investments; agricultural research institutions should be planting trees as part of their normal experimental and demonstration programmes.

Regardless of these overdue developments, agroforestry is expected to develop into a favoured form of land-use in much of our hill country. The investment, however, is likely to come from sources outside the traditional agricultural sector. Unless there is a change of attitude, the role of the farmer will be that of spectator rather than a participant.

\section{CONCLUSIONS}

Survey results imply that farmers feel they have sufficient information about forestry and agroforestry The results show that profit from trees is not their major concern. Possibly they do not yet realise the magnitude of profit that a woodlot can represent. How many farmers appreciate that a mature 30-50 hectare woodlot could make them a millionaire? And that such a woodlot could be worth more than all the livestock, buildings, plant and land in the rest of the farm?

ACKNOWLEDGEMENTS The authors would like to thank Leith Knowles and John Cawston, both of the Ministry of Forestry, and Peter Rattray, Mike O'Connor and Bruce Thorrold of the Ministry of Agriculture, for their comments and suggestions.

\section{REFERENCES}

Berl, 1988. Valuation prices for wood in New Zealand exotic forests A study commissioned by the Treasury and prepared under the auspices of Business and Economic Research Ltd. September, 1988,
Brann, G.; Brann, G. 1986. Farm scale agroforestry in the Eastern Bay of Plenty. In Maclaren. J.P. 1988 (ed.). Proceedings of the agroforestry symposium held at Rotorua, 24-27 November 1986. Ministry of Forestry, FRI Bulletin No. 139.

Butcher, D. 1986. Government policy and agroforestry. In Maclaren, ibid.

Cox 0.; McGregor, M.; Maclaren J.P. 1986. Agroforestry components of the radiata pine stand model. In Maclaren, ibid.

Gillingham, A.G.; Klomp, B.K.; Peterson, S.E. 1976. Stock and pasture management for establishment of radiata pine in farmland. Proceedings of the NZ Grassland Association 37(Z): $38-51$.

Groome, J.G. 1986. Forestry investment for individuals. In Levack, H. (ed.). 1986 Forestry Handbook. Wellington: NZ Institute of Foresters.

Hammond, D. 1986. Survey of agroforestry in New Zealand. In. Maclaren, ibid.

Hawke, M.F.; Pervical, N.Z. 1984. Grazing management of aeroforests on hill country, Aroceedinns of the NZ Grassland Association 45: 230-235

Hawke. M.F. 1989. Pasture production and Animal Performance Under Pine Agroforestry in New Zealand. Proceedings of International Agroforestry Conference, Edinburgh University, July 1989 (in prep).

Knowles, R.L.; West, G.G. 1986. Using the radiata pine anroforestrv ,model. In Maclaren. ibid.

Maclaren, J.P. (ed.) 1988. Proceedings of the agroforestry symposium held at Rotorua on 24-27 November 1986. Ministry of Forestry. FRI Bulletin No. 139.

Morev, C. 1986. Farm forestry in New Zealand: a 1985186 survey of farmer practice, intentions and opinions. In Maclaren, ibid.

O'Loughlin, C.L. 1981. Tree roots and soil stability. What's new in forest research no. 104. Forest Research Institute, Rotorua. NZ.

O'Loughlin, C.L.; Will, G.M. 1981. The effects of exotic forestry. In McColl R.H.S. and H.R. Hughes (Comp). 1981. The effects of land use, a review. Water \& Soil Miscellaneous publication no. 23. NAWASCO, Wellington.

Olsen, P.F. 1985. Limited scale logging. In Liley W.B., 1985 (Ed). Limited scale logging; the nroceedings of a seminar held in Rotorua, June 1985. NZ Logging Industry Research Assoc Inc, Box 147, Rotorua, NZ.

Percival, N.Z.; Hawke, M.F.; Jagusch, K.T.; Korte, C.J., Gillingham, A.G. 1986. Review of factors affecting animal performance in pine agroforestry. In Maclaren, ibid.

Smaller, P.G. and Meister, A.D. 1983. The practices, problems and economics of farm woodlots. Discussion paper in Natural Resource Economics no. 6, Massey University, Palmerston North.

Sutton, W.R.J. 1981. The worlds forests an inexhaustible wood supply? pp. 59-63. In proceedings of seventh Asian Plywood Manufacturers' Conference, Sydney, Oct 1981.

Trotter, C. 1988. Cyclone Bola: the inevitable diaster. New Zealand Engineering News, I July.

West, G.G.; Dean, M.G. 1986. Use of existing tree growth models on farms sites. In Maclaren, Ibid.

Whiteside, I.D. 1989. Spacing/thinning requirements in relation to product prices and exchange rates. In James, R.N. (ed.) New approaches to spacing and thinning in plantation forestry. Proceedings of IUFRO conference held at FRI, Rotorua, 10-14 April 1989. (In prep). 